$\xi=-1$

\title{
Microbial Consortium for Processing Secondary Collagen-Containing Raw Materials into Feeds for Farm Animals
}

\author{
M.M. Dragunova ${ }^{1 *}$, A.V. Pozdnyakova ${ }^{1}$, L.K. Asyakina ${ }^{1}$, O.V. Kriger, N.S. Velichkovitch ${ }^{1}$, O.V. Kozlova ${ }^{1}$, I.S. Mi- \\ lentieva ${ }^{1}$, A.Y. Prosekov ${ }^{1}$
}

${ }^{1}$ Kemerovo State University, Krasnaya Str., 6, Kemerovo, 650043, Russia

*Corresponding author E-mail: dragunova.m.m@mail.ru

\begin{abstract}
In recent years, the problem of processing and rational use of the secondary raw materials of the meat industry is becoming relevant all over the world. Pork skin or wastes accumulate in significant quantities at meat-packing plants and slaughter houses in livestock farms. There are various technologies for processing collagen-containing raw materials, but their widespread introduction to enterprises is constrained by high cost. One of the effective approaches to solving this problem is the processing of collagen-containing wastes of pig complexes by biotechnological methods. For these purposes, compositions of consortia based on yeast have collagenase activity: Clavispora lusitaniae Y-3723, Candida utilis Y-263, Candida lipotica Y-3153, Candida lipotica Y-3157, Candida arthrobotrys F-1138. The compositions of nutrient media for co-cultivation of yeast were selected: temperature, $\mathrm{pH}$, duration of cultivation. It was found that the degree of biodegradation of collagen-containing raw materials under the action of the consortia is $89.7 \%$. The mass fraction of protein in the hydrolysates of collagen-containing raw materials is $78.15 \%$, which opens prospects for their use as feed for farm animals.
\end{abstract}

Keywords: pig complex, collagen-containing waste, yeast, consortium, fodder additive.

\section{Introduction}

The main problem of feeding farm animals is the problem of consuming protein containing all the amino acids necessary for life. In this regard, the volume of feed consumption is significantly increased, productivity is reduced, the length of rearing and fattening of young animals is increasing, and the creation of one unit of production requires more feed and greater cash costs. So, due to the lack of protein in the diet, the cost of feed units increases by $2 \%$, and the digestibility of nutrient components decreases $[1,2]$. Protein deficiency also negatively affects the reproductive functions of animals, the state of their health, leads to diseases, including dystrophy $[3,4]$.

In livestock enterprises, the problem of insufficient protein intake has been acute for a long time. This is due to the fact that only $65 \%$ of the total protein nutrition is balanced. On average, the protein deficit in the rations of animals is $20-25 \%$ [5], which leads to a shortage of $30-40 \%$ of production and an increase in 1.3-1.4 times the unproductive costs for enterprises [6].

Feeds used in pig production are mostly enriched with plant proteins. At the same time, it is necessary that the feed possess a certain number of proteins of animal origin $[7,8]$. The effect of animal protein on the physiological functions of pigs is explained by a balanced amino acid composition and a high content of other nutrients, as well as a number of unidentified factors $[9,10]$. It should be noted that the introduction of protein-containing feed additives of animal origin in the diet of pigs contributes to better assimilation of plant proteins [2].

Prospective raw materials for obtaining a high-grade feed animal protein of animal origin are secondary collagen-containing raw materials, formed in large quantities in the production of meat and meat products [11]. The use of such raw materials in the food industry is no more than $25 \%$, while the disposal of secondary raw materials is prohibited at the legislative level $[9,12]$.

Each year the Russian pig farms receive up to 4,500 million tons of secondary outcomes, which ultimately not only harm the country's ecology, but also deprive the enterprise of the multimilliondollar profit from their possible use [13, 14, 15].

The aim of the work is to create a microbial consortium for the processing of secondary collagen-containing raw materials in feed for farm animals.

\section{Objects and methods of research}

The object of the study is secondary collagen-containing raw meat processing industry, namely the skin of the pigs of the Landrace breed, obtained during processing of meat under the conditions of LLC SPK Chistogorskiy (Kemerovo Region).

The following yeast strains were used to form a microbial consortium for the utilization of meat industry waste into fodder protein concentrate: Clavispora lusitaniae Y-3723, Candida utilis Y-263, Candida lipotica Y-3153, Candida lipotica Y-3157, Candida arthrobotrys F-1138, obtained from All-Russian collection of industrial microorganisms in the form of freeze dried pure cultures. Biocompatibility of yeast was tested by the method of cocultivation on dense nutrient media, characteristic for the strains studied. Cultures were considered to be biocompatible in the event that a complete "fusion" of the spots or an increase in the growth of the studied strains in the zone of co-cultivation (mutualism, synergism, satellism). 
Sampling was conducted in accordance with GOST R 51447-99 "Meat and meat products. Sampling methods"; GOST R 51448-99 "Meat and meat products. Methods for preparation of samples for microbiological analysis".

Determination of total nitrogen / protein was performed using a RAPID N ELEMENTAR protein analyzer. The principle of the method is to determine nitrogen by burning the analyte of a known mass under conditions of high temperature (about $900{ }^{\circ} \mathrm{C}$ ) of the chamber in the presence of oxygen, which results in the release of carbon dioxide, water and nitrogen, the mass fraction of which is detected by the device. The total protein content was calculated by multiplying the total nitrogen by the recalculating factor for proteins, which is 6.25 .

The determination of collagen was carried out under conditions of heating the sample at $42-44{ }^{\circ} \mathrm{C}$ for 2 hours followed by treatment with an acetone solution of tetrachloroparachinone in the presence of 1.4-dioxane, and the resulting colored solution was photographed at a wavelength of $547 \mathrm{~nm}$ [4].

The collagenase activity was determined from the content of hydroxyproline in the mixture formed as a result of the action of the enzyme on native collagen [16].

\section{Results and discussion}

A full analysis of the chemical composition of the secondary collagen-containing raw material of pig complexes was made in [17] (pig skin from the pigs of the Landras breed (LLC SPK Chistogorskiy, Kemerovo Region)) .The obtained data allowed to conclude that the selected samples are an extremely valuable source substances necessary for the animal body. This gives grounds to use it as a source of protein substances in the development of feed for farm animals.

The data obtained make it possible to conclude that the samples under study are an exceptionally valuable source of substances necessary for the animal organism. This gives grounds for using it as a source of protein substances in the development of feed for farm animals.

However, in addition to the complex organic composition, the waste of meat processing plants is characterized by a high level of contamination with pathogenic microflora. It is known that collagen-containing waste is a favorable medium for the growth of potentially pathogenic microorganisms, such as Escherichia coli and coliform bacteria, Clostridium sp., Enterococcus sp., Listeria sp., Campylobacter sp. [5].

In connection with this, the strains for the microbial consortium were selected taking into account the presence of antagonistic activity and the ability to produce several subclasses of enzymes simultaneously or sequentially, depending on the presence of the substrate. Thus, Clavispora lusitaniae Y-3723 is a producer of collagenase, an antagonist of Esherichia coli; Candida utilis Y263 is a producer of protein biomass; Candida lipotica Y-3153, Candida lipotica Y-3157 - producers of lipolytic enzymes, Salmonella typhimurium antagonists; Candida arthrobotrys F-1138 is a producer of collagenase, the antagonist Streptococcus pyogenes. When composing symbiotic consortiums based on selected strains, the following criteria should be followed: the specific properties that the selected yeasts possess; peculiarities of the metabolism of microorganisms; biocompatibility of microorganisms; conditions of cultivation of microorganisms (duration of cultivation, temperature and $\mathrm{pH}$, composition of nutrient medium). The data on the biocompatibility of the selected strains with each other in combination are presented in Table 1 .
Table 1: Biocompatibility of strains of microorganisms

\begin{tabular}{|c|c|c|c|c|c|}
\hline Strain & $\begin{array}{c}\text { Clavispora } \\
\text { lusitaniae } \\
\text { Y-3723 }\end{array}$ & $\begin{array}{c}\text { Candida } \\
\text { utilis } \\
\text { Y-263 }\end{array}$ & $\begin{array}{c}\text { Candida } \\
\text { lipotica } \\
\text { Y-3153 }\end{array}$ & $\begin{array}{c}\text { Candida } \\
\text { lipotica } \\
\text { Y-3157 }\end{array}$ & $\begin{array}{c}\text { Candida } \\
\text { arthrobotrys } \\
\text { F-1138 }\end{array}$ \\
\hline $\begin{array}{c}\text { Clavispora } \\
\text { lusitaniae } \\
\text { Y-3723 }\end{array}$ & - & БC & CA & CA & БC \\
\hline $\begin{array}{c}\text { Candida } \\
\text { utilis } \\
\text { Y-263 }\end{array}$ & 5C & - & БC & БC & БC \\
\hline $\begin{array}{c}\text { Candida } \\
\text { lipotica } \\
\text { Y-3153 }\end{array}$ & CA & БC & - & БC & CA \\
\hline $\begin{array}{c}\text { Candida } \\
\text { lipotica } \\
\text { Y-3157 }\end{array}$ & СА & БC & БC & - & CA \\
\hline $\begin{array}{c}\text { Candida } \\
\text { arthrobotrys } \\
\text { F-1138 }\end{array}$ & 5C & БC & CA & CA & - \\
\hline
\end{tabular}

Biocompatibility is observed for combinations: Clavispora lusitaniae Y-3723 + Candida utilis Y-263; Clavispora lusitaniae Y-3723 + Candida arthrobotrys F-1138; Candida utilis Y-263 + Candida lipotica Y-3153; Candida utilis Y-263 + Yarrowia lipotica Y-3157; Candida utilis Y-263 + Candida arthrobotrys F-1138; Candida lipotica Y-3153 + Candida lipotica Y-3157. Weak antagonism is manifested in the case of cocultivation of strains: Clavispora lusitaniae Y-3723 + Candida lipotica Y-3153; Clavispora lusitaniae Y-3723 + Candida lipotica Y-3157; Candida lipotica Y-3153 + Candida arthrobotrys F-1138; Candida lipotica Y-3157 + Candida arthrobotrys F-1138.

On the basis of the results obtained on the study of the inter-strain interaction of yeast, consortia consisted of consortia. For this purpose, the conditions for the joint cultivation of the strains were determined, the optimal composition of the nutrient medium, the temperature and the $\mathrm{pH}$ were selected. The compositions of the consortia under study are presented in Table 2.

Table 2: The compositions of the studied consortia of microorganisms

\begin{tabular}{|c|l|}
\hline $\begin{array}{c}\text { Consortium } \\
\text { number }\end{array}$ & \multicolumn{1}{c|}{ Composition of the consortium } \\
\hline 1 & $\begin{array}{l}\text { Clavispora lusitaniae } \text { Y-3723, Candida utilis } \mathrm{Y}-263, \\
\text { Candida arthrobotrys } \mathrm{F}-1138, \text { ratio of microorganisms } \\
1: 1: 1\end{array}$ \\
\hline 2 & $\begin{array}{l}\text { Candida utilis } \mathrm{Y}-26, \text { Clavispora lusitaniae } \mathrm{Y}-3723, \text { Can- } \\
\text { dida lipotica } \mathrm{Y}-3153, \text { Candida lipotica } \mathrm{Y}-315, \text { Candida } \\
\text { arthrobotrys } \mathrm{F}-1138, \text { ratio of microorganisms } 1: 1: 1: 1: 1\end{array}$ \\
\hline 3 & $\begin{array}{l}\text { Candida lipotica } \mathrm{Y}-315, \text { Candida lipotica } \mathrm{Y}-3153, \\
\text { Candida utilis } \mathrm{Y}-263, \text { ratio of microorganisms } 1: 1: 1\end{array}$ \\
\hline
\end{tabular}

From the literature sources the composition of the nutrient medium for the cultivation of all yeast $(\mathrm{g} / \mathrm{l})$ used in the consortium is known: glucose-20, peptone-10, yeast extract-5, bacteriological agar-20.

The optimal composition of the nutrient medium for the cultivation of the three consortia of microorganisms studied was selected by the addition of mineral salts such as potassium phosphate 1substituted and sodium chloride and subsequent measurement of the microorganism concentration. The compositions of the culture media are shown in Table 3. Cultivation was carried out at a temperature of $25.0 \pm 2.0^{\circ} \mathrm{C}$ and a pH of $7.0 \pm 0.2$ for $24 \mathrm{~h}$. 
Table 3: Compositions of nutrient media for the cultivation of yeast consortia

\begin{tabular}{|c|c|c|}
\hline \multirow{2}{*}{ Component } & $\begin{array}{c}\text { Content } \\
\text { of component, g/l }\end{array}$ & $\begin{array}{c}\text { Content } \\
\text { of component, g/l }\end{array}$ \\
\cline { 2 - 3 } & Medium No. 1 & Medium No. 2 \\
\hline Glucose & 20 & 20 \\
\hline Peptone & 10 & 10 \\
\hline Yeast Extract & 5 & 5 \\
\hline Bacteriological agar & 20 & 20 \\
\hline $\begin{array}{c}\text { Potassium phosphate } \\
\text { 1-substituted }\end{array}$ & 0,1 & - \\
\hline Sodium chloride & - & 1,0 \\
\hline
\end{tabular}

The results of assessing the viability of consortia 1-3 cultivated under the selected conditions on nutrient media of different composition are shown in Figure 1.

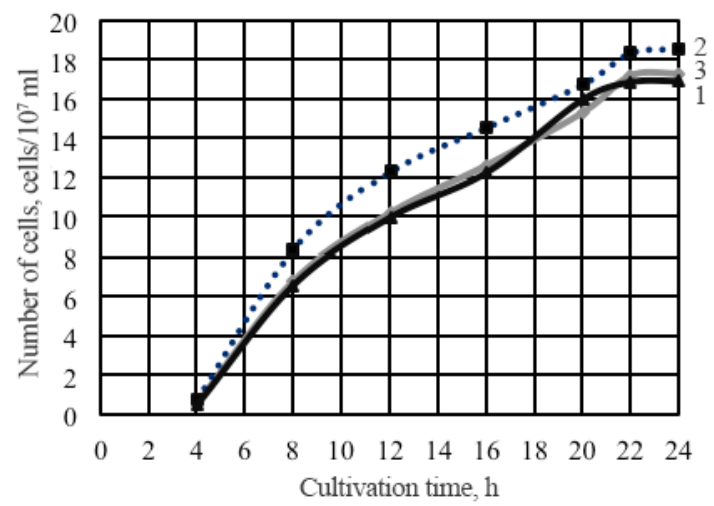

a

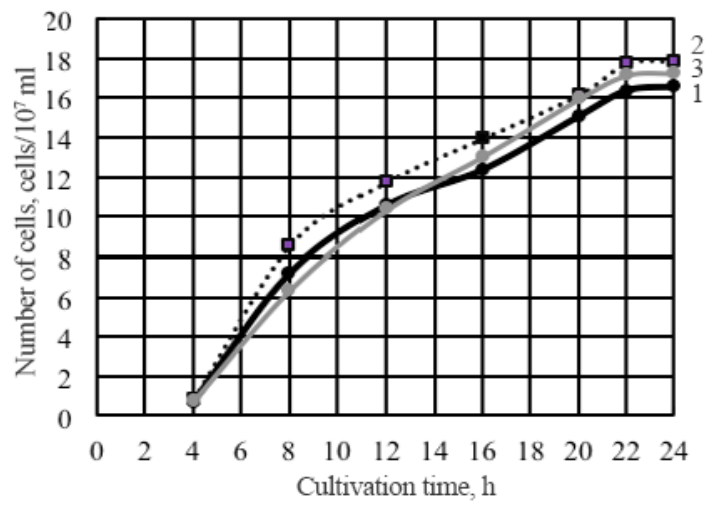

b

Fig. 1: Dynamics of growth of yeast cells within 24 hours on nutrien media No. 1-a and No. 2-b (1,2,3 - consortia of microorganisms)

The analysis of the results shown in Figure 2 shows that the maximum number of yeast cells is reached when the strains of consortium No. 2 are cultivated. The largest growth indicator was recorded on nutrient medium No. $1\left(18.6\right.$ cells $\left./ 10^{7} \mathrm{ml}\right)$ with a cultivation time of 24 hours (Figure 2).

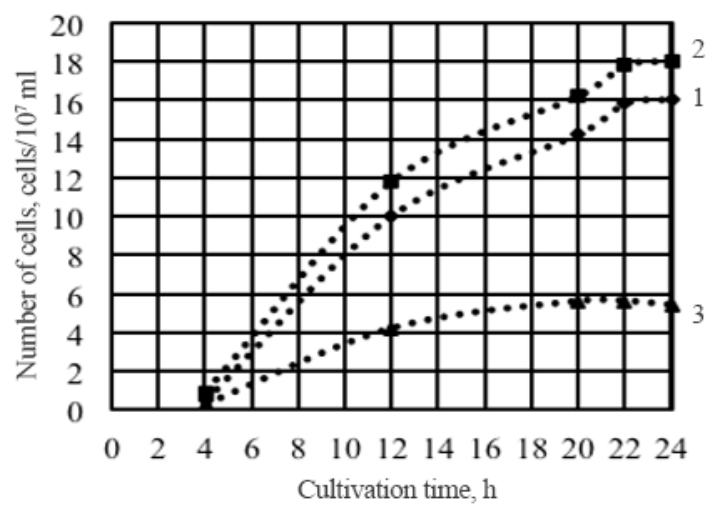

a

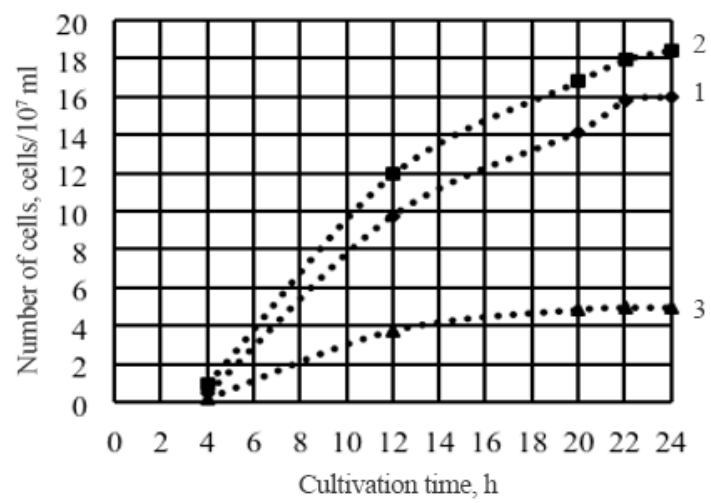

$\mathrm{b}$

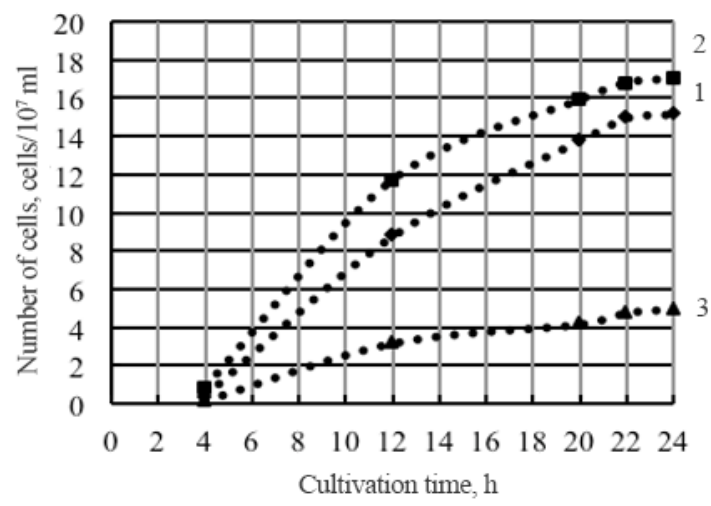

c

Fig. 2: Dynamics of growth of yeast cells within 24 hours on nutrient medium No. 1 at $\mathrm{pH} 7.0$ and at various temperatures: $1-20{ }^{\circ} \mathrm{C}, 2-25{ }^{\circ} \mathrm{C}$, 3-30 ${ }^{\circ} \mathrm{C}(\mathrm{a}-$ consortium $1, \mathrm{~b}-$ consortium $2, \mathrm{c}-$ consortium 3$)$

Studies were conducted on the selection of optimal temperature values and $\mathrm{pH}$ on nutrient media of the chosen composition for the process of co-cultivation of consortia of microorganisms ensuring maximum cell viability.

Cultivation of consortia studied on nutrient medium No. 1 and No. 2 at $\mathrm{pH} 7.0 \pm 0.2$ and different temperature regimes: 20, 25, $30{ }^{\circ} \mathrm{C}$ was carried out. The results of the studies are shown in Figure 3. 


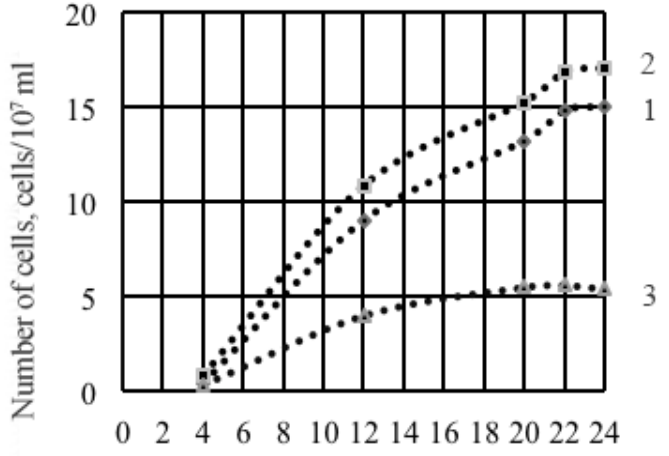

Cultivation time, $\mathrm{h}$
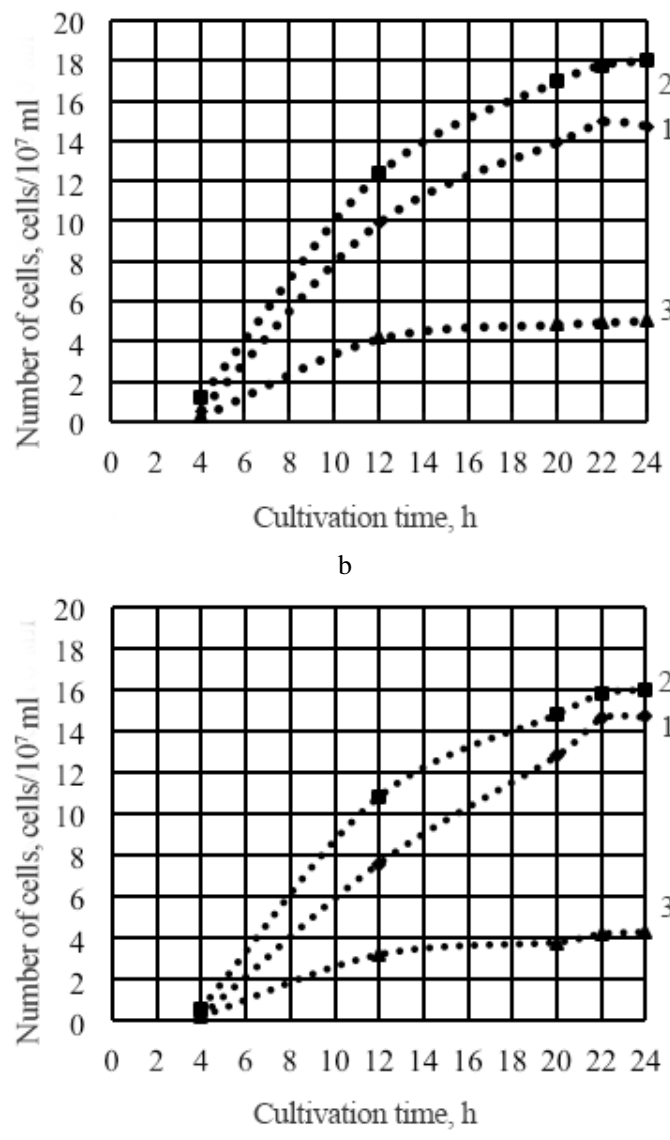
$\mathrm{c}$

Fig. 3: Dynamics of growth of yeast cells within 24 hours on nutrient medium No. 2 at $\mathrm{pH} 7.0$ and different temperatures: $1-20^{\circ} \mathrm{C}, 2-25^{\circ} \mathrm{C}$, $3-30^{\circ} \mathrm{C}(\mathrm{a}-$ consortium $1, \mathrm{~b}-$ consortium $2, \mathrm{c}-$ consortium 3$)$

Analysis of the results presented in Figures 2 and 3 shows that the maximum number of yeast cells is achieved by cultivating the strains of consortium No. 2 on nutrient medium No. 1 (18.7 cells $\times$ $10^{7} \mathrm{ml}$ ) at a temperature of $25^{\circ} \mathrm{C}$. and the duration of cultivation for 24 hours.

In order to select the optimal $\mathrm{pH}$ of the culture medium for the cultivation of the symbiotic yeast consortium, $\mathrm{pH}$ values ranging from 6.5 to 7.5 were varied. The composition of the nutrient medium for each consortium studied was identical to the previous experiment. The culturing temperature was $25{ }^{\circ} \mathrm{C}$. The results of studies on the selection of the optimum $\mathrm{pH}$ of the nutrient medium for different duration of cultivation are presented in Figures 4 and 5.

Analysis of the results presented in Figures 4 and 5 shows that the maximum concentration of microorganisms is reached at a $\mathrm{pH}$ value of $7.0 \pm 0.2$. Thus, the maximum concentration of microorganisms in Consortium No. 1 is 19.23 cells $/ 10^{7} \mathrm{ml}$ when cultivat- ed on nutrient medium No. 1 at a temperature of $25^{\circ} \mathrm{C}$, the duration of the process is 24 hours and at $\mathrm{pH}$ 7.0. The maximum concentration of microorganisms of consortium No. 2 is $18.3 \mathrm{kl} \times$ $10^{7} \mathrm{ml}$ when cultivated on nutrient medium No. 1 at a temperature of $25{ }^{\circ} \mathrm{C}, \mathrm{pH} 7.0$ and the duration of the process is 24 hours. The yeast consortium No. 3, cultivated at $25{ }^{\circ} \mathrm{C}$, and the duration of the cultivation process $24 \mathrm{~h}$ on nutrient medium No. 2, showed the maximum cell concentration (17.34 cells $\left./ 10^{7} \mathrm{ml}\right)$ at $\mathrm{pH}$ 7.0.
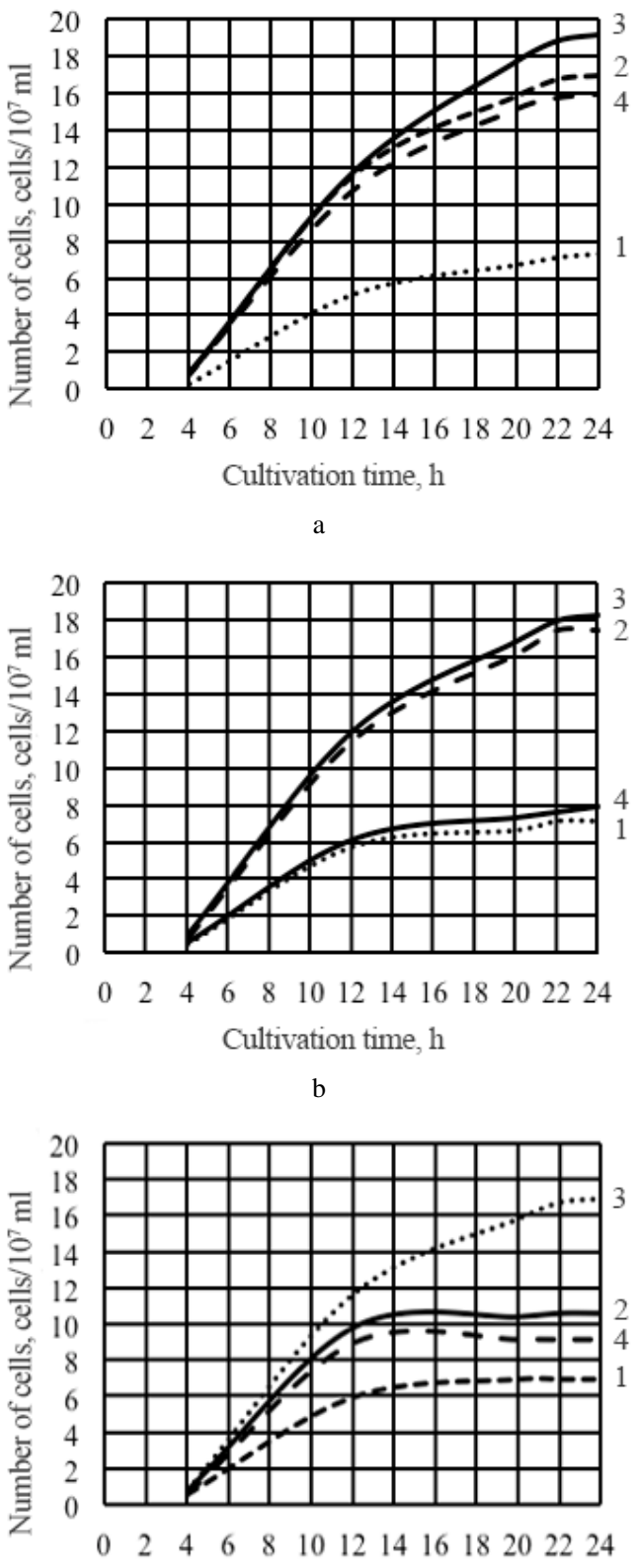

Cultivation time, $\mathrm{h}$

Fig. 4: Dynamics of growth of yeast cells for 24 hours on nutrient medium No. 1 at a temperature of $25{ }^{\circ} \mathrm{C}$ and $\mathrm{pH}$ in the range from 6.5 to 7.5 ( $\mathrm{a}$ - consortium $1, \mathrm{~b}$ - consortium $2, \mathrm{c}$ - consortium 3 ) 


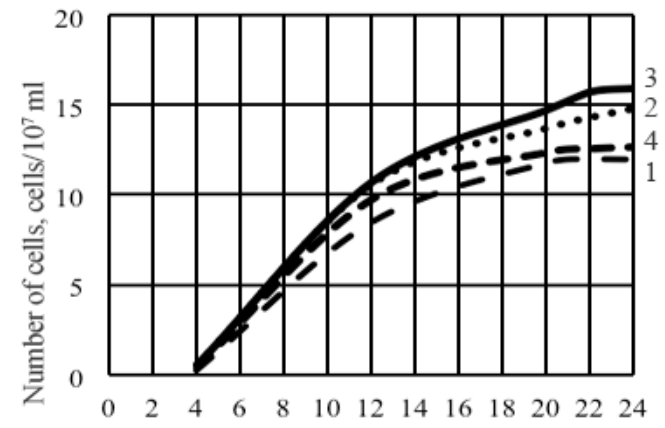

Cultivation time, $\mathrm{h}$

a

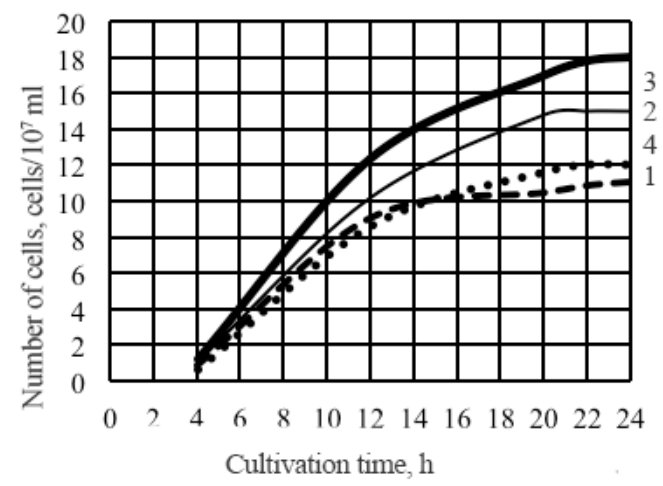

b

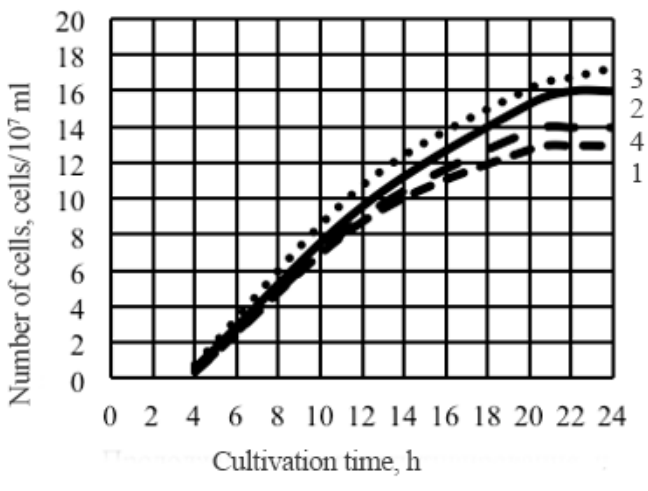

$\mathrm{c}$

Fig. 5: Dynamics of growth of yeast cells for 24 hours on nutrient medium No. 2 at a temperature of $25^{\circ} \mathrm{C}$ and $\mathrm{pH}$ in the range from 6.5 to 7.5 (a- consortium $1, \mathrm{~b}$ - consortium $2, \mathrm{c}-$ consortium 3 )

Thus, optimal conditions for cultivation of symbiotic consortia of microorganisms possessing collagenase activity were selected (Table 4).

Table 4: Optimal conditions for the cultivation of symbiotic consortia of microorganisms

\begin{tabular}{|c|c|c|c|}
\hline \multirow{2}{*}{ Consortium number } & \multicolumn{3}{|c|}{ Conditions for cultivation } \\
\cline { 2 - 4 } & Nutrient medium number & $\begin{array}{c}\text { Temperature, } \\
{ }^{\circ} \mathrm{C}\end{array}$ & $\mathrm{pH}$ \\
\hline 1 & №1 & $25.0 \pm 2.0$ & $7.0 \pm 0.2$ \\
\hline 2 & №1 & $25.0 \pm 2.0$ & $7.0 \pm 0.2$ \\
\hline 3 & №2 & $25.0 \pm 2.0$ & $7.0 \pm 0.2$ \\
\hline
\end{tabular}

Then, the conditions were chosen to carry out biodegradation of meat processing waste by a consortium of microorganisms with collagenase activity. Previously, the transfer of collagen waste meat processing industry in a soluble form.

In order for proteolytic enzymes to properly influence the protein, it was rebuilt into a denatured form by grinding the raw material and conducting an alkaline hydrolysis with a solution of the following composition: ammonium sulfate, hydrogen peroxide and sodium hydroxide.

The alkaline hydrolysis of the crushed raw material was carried out for 2.0; 4.0; 6.0; and 8.0 hours. According to the results ob- tained, the highest solubility of collagen-containing waste is observed with 8-hour hydrolysis, the content of the dissolved protein in this case reaches $91.3 \%$ (Figure 6). Accordingly, it was concluded that in order to increase the bioavailability of components of secondary collagen-containing waste meat plants for enzymes released by the microorganisms included in the consortium, it is best to use alkaline hydrolysis for 8.0 hours.

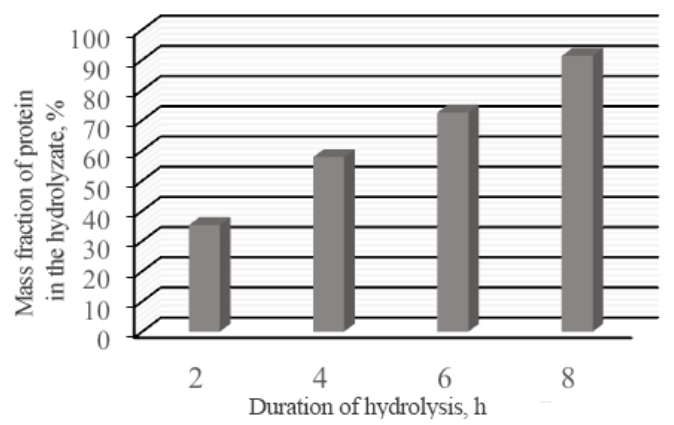

Fig. 6: Effect of the duration of alkaline hydrolysis on the mass fraction of soluble protein in the hydrolysate

In the denatured form, collagen can also be converted by other methods: acid hydrolysis, hydrolysis by urea under pressure, hydrothermal treatment.

Therefore, further research of these methods on the ability to translate collagen into a denatured form was conducted. The results of the experiments are shown in Table 5.

Table 5: Solubility of collagen-containing raw materials depending on the duration of different types of hydrolysis

\begin{tabular}{|c|c|c|c|}
\hline \multirow[b]{2}{*}{$\begin{array}{l}\text { Duration of } \\
\text { hydrolysis, h }\end{array}$} & \multicolumn{3}{|c|}{ Mass fraction of soluble protein in the hydrolyzate, $\%$} \\
\hline & $\begin{array}{c}\text { Acid } \\
\text { hydrolysis }\end{array}$ & $\begin{array}{l}\text { Hydrolysis } \\
\text { by urea }\end{array}$ & Hydrothermal treatment \\
\hline 2.0 & $17.0 \pm 0.5$ & $21.3 \pm 0.6$ & $27.6 \pm 0.7$ \\
\hline 4.0 & $21.3 \pm 0.6$ & $27.5 \pm 0.7$ & $35.6 \pm 1.1$ \\
\hline 6.0 & $37.3 \pm 1.1$ & $41.3 \pm 1.2$ & $52.5 \pm 1.5$ \\
\hline 8.0 & $41.5 \pm 1.2$ & $51.3 \pm 1.5$ & $70.3 \pm 2.1$ \\
\hline
\end{tabular}

Based on the results of Table 5, it can be seen that 8-hour alkaline hydrolysis and hydrothermal treatment are the most effective methods of transferring collagen into a dissolved form, allowing to obtain $91.3 \%$ and $70.3 \%$ of the dissolved protein, respectively. Acid hydrolysis and urea processing by the raw materials proved to be less effective methods, allowing to obtain only $41.5 \%$ and $51.3 \%$ of the dissolved protein.

On the basis of the results obtained, to increase the bioavailability of waste components of the meat processing industry for microorganisms - destructors included in the consortium, preliminary alkaline hydrolysis with a solution containing ammonium sulfate, hydrogen peroxide and sodium hydroxide.

Further, the degree of biodegradation of the secondary collagencontaining raw material was determined under the action of the created symbiotic consortia (Figure 7).

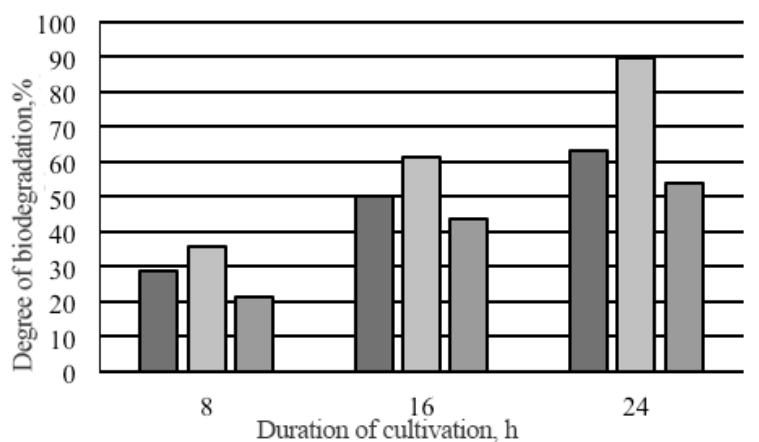

Fig. 7: Histogram of increasing the degree of biodegradation of collagencontaining raw materials depending on the duration of cultivation of consortia ( $\mathrm{a}$ - consortium $1, \mathrm{~b}$ - consortium $2, \mathrm{c}$ - consortium 3 )

From figure 7 it follows that the maximum value of the degree of biodegradation of meat processing industry wastes $(89.7 \%)$ is 
achieved by hydrolysis by a consortium of yeast - destructors No. 2, cultivated at $\mathrm{pH} 7.0$ and temperature $25^{\circ} \mathrm{C}$ for 24.0 hours. Thus, Consortium No. 2 was chosen for the hydrolysis of meat industry waste.

One of the main parameters is the ratio of seed volume to the volume of processed raw materials. In this connection, a series of experiments on the hydrolysis of meat processing wastes by a consortium of yeast destructors No. 2 (ratio of strains 1:1:1:1:1), cultivated together at $\mathrm{pH} 7.0$ and $25^{\circ} \mathrm{C}$, varied the ratio of seed volume to volume of processed raw materials (1:2.0, 1:5.0, 1:10.0). The results are shown in Figure 8.

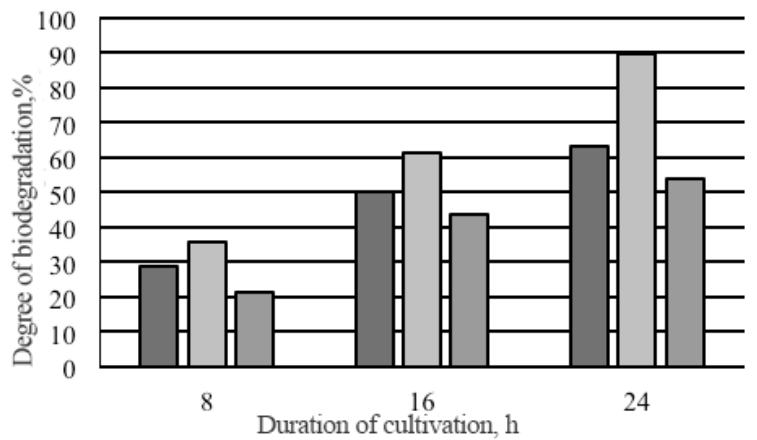

Fig. 8: Dependence of the degree of biodegradation of collagen-containing raw materials by a consortium of microorganisms No. 2 from the duration of cultivation at a temperature of $25{ }^{\circ} \mathrm{C}, \mathrm{pH} 7.0$ and different ratio of seed volume to volume of processed raw materials: $1-1: 2.0 ; 2: 1: 5.0 ; 3-1: 10.0$

The results shown in Figure 8 indicate that at a ratio of seed volume to processed feed 1: 5.0, the hydrolysis reaction of the secondary meat-processing raw material passes with maximum efficiency (85.6\% of biodegradation)

Further, the hydrolyzate of meat processing wastes obtained by the action of the yeast-destructor consortium on the content of crude protein (according to GOST R 50257-92, the mass fraction of crude protein in the pig feed should be at least $15 \%$ ). The mass fraction of crude protein in the hydrolyzate of collagen-containing raw material is $78.15 \%$. This indicates that the sample of the hydrolyzate contains a valuable concentrate of polymers necessary for the animal body. This gives grounds for using it as animal feed for the agricultural sector.

\section{Conclusion}

The biocompatibility of five strains - yeast, possessing collagenase activity was investigated. It was found that biocompatibility is observed for combinations: Clavispora lusitaniae Y-3723 + Candida utilis Y-263; Clavispora lusitaniae Y-3723 + Candida arthrobotrys F-1138; Candida utilis Y-263 + Candida lipotica Y3153; Candida utilis Y-263 + Yarrowia lipotica Y-3157; Candida utilis Y-263 + Candida arthrobotrys F-1138; Candida lipotica Y$3153+$ Candida lipotica Y-3157. Weak antagonism is manifested in the case of cocultivation of strains: Clavispora lusitaniae $\mathrm{Y}$ 3723 + Candida lipotica Y-3153; Clavispora lusitaniae Y-3723 + Candida lipotica Y-3157; Candida lipotica Y-3153 + Candida arthrobotrys F-1138; Candida lipotica Y-3157 + Candida arthrobotrys F-1138.

The conditions for biodegradation of collagen-containing raw materials by a consortium consisting of five microorganisms destructors (ratio of strains 1:1:1:1:1): $25^{\circ} \mathrm{C} ; \mathrm{pH} 7.0$; duration of cultivation $16.0 \mathrm{~h}$; ratio of seed volume to processed feed 1:5.0. The analysis of enzymatic hydrolysates of collagen-containing raw material on the content of crude protein was carried out. Mass fraction, which is equal to $78.15 \%$. This indicates that the sample of the hydrolyzate contains a valuable concentrate of polymers necessary for the animal body. This gives grounds for the advisability of using collagen hydrolyzate as a high-protein, nutritionally balanced animal feed for the agricultural sector.

\section{References}

[1] Morozova AI, Babich OO, Razumnikova IS (2011), Processing of secondary keratin-containing raw materials and production of protein hydrolysates for food and feed purposes. Technique and technology of food production, V. 21, №2, pp: 7-11.

[2] Monteiro ANTR, Garcia-Launay F, Brossard L, Wilfart A, Dourmad J-Y (2016), Effect of feeding strategy on environmental impacts of pig fattening in different contexts of production: Evaluation through life cycle assessment. Journal of Animal Science, V. 94, I. 11, pp: 4832-4847.

[3] Antipova LV, Selezneva LV, Grebenshchikov AV (2011), Ways of rational use of low-grade raw materials with application of biotechnological processing methods. Meat Industry, №4, pp: 74-76.

[4] Dragunova MM, Brekhova VP (2014), Method for processing secondary collagen-containing raw materials using yeast Clavispora lusitaniae Y3723. Technique and technology of food production, V. 32, №1, pp: 18-21.

[5] Zeugswetter FK, Zwack D, Luckschander-Zeller N, Schwendenwein I (2017), The acute effects of a protein-rich meal on the urinary corticoid:creatinine ratio in healthy dogs. Journal of Animal Physiology and Animal Nutrition, V. 101, I. 1, pp: 75-80.

[6] Andretta I, Hauschild L, Kipper M, Pires PGS, Pomar C (2017), Environmental impacts of precision feeding programs applied in pig production. Animal, pp: 9.

[7] Pedersen MB, Plumstead P, Dalsgaard S (2012), Comparison of four feed proteases for improvement of nutritive value of poultry feather meal. Journal of animal science, V. 90, No. 4, pp: 350-352.

[8] Ertl P, Knaus W, Zollitsch W (2016), An approach to including protein quality when assessing the net contribution of livestock to human food supply. Animal, V. 10, I. 11, pp: 1883-1889.

[9] Agadzhanyan AE, Oganisyan GZ, Vardanyan AA, Egiyan KI (2014), The production of amino acids as a result of complex processing of protein-containing raw materials. Biotechnology, №3, pp: 55-61.

[10] Piskaeva AI, Sidorin YY, Dyshlyuk LS, Zhumaev YV, Prosekoy AY and Coli Bacteria E (2014), Research on the Influence of Silver Clusters on Decomposer Microorganisms. Food and Raw Materials, No. 1, pp: 62-66.

[11] Linnik AI (2012), Functional processing of downy-perch waste with the use of a strain of overproduction. Collection of works of the winners of the qualifying round of the All-Russian review of the contest of scientific and technical creativity of students of universities "Eureka", pp: 122-123.

[12] Fayvishevsky ML (2013), On processing of non-food raw materials and environmental protection. Meat industry, No. 9, pp: 66-69.

[13] Piskayeva AI, Prosekov AYu (2016), Optimization of parameters of cultivation of a consortium of microorganisms - keratin destructors in biotechnological purposes. Izvestiya ISU, №16, pp: 53-61.

[14] Prosekov AYu, Babich OO, Soldatova LS (2012), Experience of the department "Bionanotechnology" of the Kemerovo technological institute of the food industry in the field of biotechnology for obtaining recombinant enzyme preparations. Technique and technology of food production, V. 3, № 26, pp: 102-111.

[15] Poletaev AYu (2011), Development of technology for processing keratin-containing raw materials using Streptomyces ornatus $S$-1220 \dissertation of cand. of tech. sciences: 05.18.04. Kemerovo, $130 \mathrm{p}$.

[16] Shishkina EF (1999), Investigation of some physical and chemical properties of Penicillium wortmannii proteinase \graduation qualification work in specialty 011000 "Chemistry". Voronezh, 73 p.

[17] Dragunova MM, Linnik AI, Piskayeva AI (2015), Study of the chemical composition of pigskins for the development of biotechnological processing of meat wastes. Materials of the all-Russian scientific and practical conference of young scientists, graduate students and students "Ecology and safety in the technosphere: modern problems and solutions". Yurga, pp: 32-35. 